\title{
Saline water and biofertilizer from bovine and goat manure in the Lima bean crop
}

\author{
Maria Vanessa Pires de Souza ${ }^{1}$, Geocleber Gomes de Sousa ${ }^{1} \oplus$, Jonnathan Richeds da Silva Sales ${ }^{1} \oplus$,

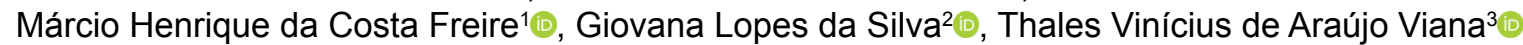

\footnotetext{
1 Universidade da Integração Internacional da Lusofonia Afro-Brasileira, Instituto de Desenvolvimento Rural, Redenção, CE, Brasil. E-mail: vanessa.pires1993@gmail.com sousagg@unilab.edu.br; jonnathanagro@gmail.com; marciohcfreire@gmail.com

2 Instituto Federal do Maranhão, Campus Codó, Codó, MA, Brasil. E-mail: gisolos@hotmail.com

${ }^{3}$ Universidade Federal do Ceará, Centro de Ciências Agrárias, Departamento de Engenharia Agrícola, Fortaleza, CE, Brasil. E-mail: thales@ufc.br
}

ABSTRACT: The use of organic fertilizer may attenuate the deleterious effects of saline stress. This study aimed to evaluate the response of the lima bean crop at different levels of saline water in the soil, with and without bovine and goat biofertilizer. The experiment was conducted in the period from March to April 2017, at the experimental area of the Federal University of Ceará, Fortaleza, Ceará. The experimental design was a completely randomized treatment in a $5 \times 3$ factorial arrangement, with five replications. The treatments were composed by five levels of electrical conductivity from the irrigation water - Ecw: $0.5 ; 1.5$; 2.5; 3.5 and $4.5 \mathrm{dS} \mathrm{m}^{-1}$, applied in vessels without and with bovine and goat biofertilizer. The following variables were analyzed: the electrical conductivity of the soil saturation extract, root length, stem diameter, number of leaves, leaf area, shoot and root dry weight, photosynthesis, transpiration and stomatal conductance. Goat biofertilizer attenuated the saline stress with more efficiency for the growth and dry weight variables. Plants fertilized with bovine biofertilizer have higher values of photosynthetic rate, transpiration rate and stomatal conductance than the plants with goat manure.

Key words: organic fertilizer; Phaseolus lunatus L.; salt stress

\section{Água salina e biofertilizantes de esterco bovino e caprino na salinidade do solo, crescimento e fisiologia da fava}

RESUMO: O fertilizante orgânico pode atenuar os efeitos deletérios do estresse salino. 0 objetivo desse trabalho foi avaliar a resposta da cultura da fava a diferentes níveis de água salina em substrato sem e com biofertilizante bovino e caprino. O experimento foi conduzido no período de março a abril de 2017, na Universidade Federal do Ceará, Fortaleza, Ceará. 0 delineamento experimental foi inteiramente casualizado em esquema fatorial $5 \times 3$, com cinco repetições. Os tratamentos foram constituídos de cinco níveis de condutividade elétrica da água de irrigação - Cea de: 0,$5 ; 1,5 ; 2,5 ; 3,5$ e 4,5 dS m-1 em substrato sem e com biofertilizante bovino e caprino. Foram avaliadas: condutividade elétrica do extrato de saturação do solo, comprimento da raiz, diâmetro do caule, número de folhas, área foliar, matéria seca da parte aérea, da raiz, fotossíntese, transpiração e condutância estomática. $O$ biofertilizante caprino atenuou o estresse salino com mais eficiência para as variáveis de crescimento e matéria seca. As plantas de fava adubadas com biofertilizante bovino apresentam maiores valores de taxa fotossintética, taxa de transpiração e condutância estomática do que às plantas que o de esterco caprino.

Palavras-chave: adubo orgânico; Phaseolus lunatus L.; estresse salino 


\section{Introduction}

Lima bean (Phaseolus lunatus L.) belongs to the Fabaceae family and is one of the main legumes grown in the tropical region, providing both an income and food source. Despite its socioeconomic importance, productivity has been decreasing, a fact that is associated with the low rate of management technologies use. Moreover, the planting of traditional varieties with low production capacity and a lack of studies on the saline irrigation management for the crop has also contributed to the low yield and economic return, making lima bean practically a subsistence crop (Oliveira et al., 2011).

Low rainfall and the high evaporation rate have also contributed to the salinization and/or sodification processes of the semiarid regions soils, since the salts are not leached and accumulate in large amounts in the soil, hindering the cultivated plants development (Vasconcelos et al., 2013). Regardless of its source, water used for irrigation always contains salts that, generally, vary significantly in quality and quantity (Cavalcante et al., 2011). As for plant species, the effects of salinity and/or sodicity vary between species and genotypes of the same species (Neves et al., 2009).

Salinity is one of the major environmental stresses that negatively affect both the plant growth and its metabolism, by reducing the osmotic potential from soil solution (Sá et at., 2016). Excess salt may also compromise plant physiological functions, causing stomatal closure, limiting the internal $\mathrm{CO}_{2}$ concentration (Gomes et al., 2015) and decreasing both the photosynthesis and transpiration rates (Lima et al., 2015).

Biofertilizers have been used in plants grown in saline soil in order to attenuate the salts effect, as a sustainable and economical alternative. It releases humic substances into the soil, facilitating the absorption of essential elements to plant and thus favoring a higher initial growth of them in saline environments (Sousa et al., 2014).

Given the above, the objective was to evaluate the response of lima bean to different levels of saline water in substrate in the presence and absence of bovine and goat biofertilizer.

\section{Materials and Methods}

The experiment was held from March to April 2017, in a screened greenhouse belonging to the experimental area from the Federal University of Ceará, Fortaleza-CE. According to
Köppen (1923), the climate of the region is classified as Aw', rainy tropical, very hot with predominant rains from January to May.

The substrate material was a 2:1 mixture of sand and manure, respectively. Its chemical attributes before the treatment application are displayed in Table 1.

Sowing of the lima bean seeds, from the 'Milagrosa' cultivar, was carried out in plastic pots with $14 \mathrm{~L}$ capacity. After the establishment of the plants, at eight days after sowing (DAS), the thinning was done, leaving only the most vigorous plant per pot.

The experimental design was completely randomized, using a $5 \times 3$ factorial scheme with five replications, referring to the electrical conductivity levels of the irrigation water - Ecw: $0.5 ; 1.5 ; 2.5 ; 3.5$ and $4.5 \mathrm{dS} \mathrm{m}^{-1}$, in the soil without biofertilizer (B0), with bovine (B1) and goat (B2) biofertilizers.

The amount of $\mathrm{NaCl}, \mathrm{CaCl}_{2} \cdot 2 \mathrm{H}_{2} \mathrm{O}, \mathrm{MgCl}_{2} \cdot 6 \mathrm{H}_{2} \mathrm{O}$ salts used to prepare the irrigation waters was determined in order to obtain the desired ECW in a 7:2:1 ratio respectively, following the relation between $\mathrm{ECW}$ and its concentration $\left(\mathrm{mmol}_{\mathrm{C}} \mathrm{L}^{-1}\right.$ $=E C \times 10$ ) (Rhoades et al., 2000). Irrigation began after the thinning (10 days after emergence) at a daily frequency and using the weighing method described by Puértolas et al. (2017), i.e., providing the water volume at every $24 \mathrm{~h}$ to keep the substrate at field capacity.

Bovine and goat biofertilizers were prepared from a mixture of equal parts from each type of fresh manure and non-saline water (electrical conductivity of water $[\mathrm{ECw}]=0.8$ $\mathrm{dS} \mathrm{m}^{-1}$ ) under aerobic fermentation for 30 days, in a plastic container. Each biofertilizer was applied twice (at 8 and 16 DAS), in volumes equivalent to $10 \%$ (700 mL plant $\left.{ }^{-1}\right)$ of the substrate volume (Viana et al., 2013).

Nutrient levels ( $N, P, K, C a, M g, F e, C u, Z n$ and $M n$ ) in the chemical composition of liquid biofertilizers are displayed in Table 2. All analyzes were performed using the methodologies suggested by Embrapa (1997).

At 45 DAS, the electrical conductivity from soil saturation extract (ECse), leaf number (LN), leaf area (LA), stem diameter (SD), root length (RL), shoot dry weight (SDW), root dry weight (RDW), and the following physiological indices: net photosynthetic rate $(A)$, transpiration rate $(E)$ and stomatal conductance (gs) were all analyzed. Measurements were performed by using an infrared gas analyzer (LCi System, ADC, Hoddesdon, UK), in open-air system, with a $300 \mathrm{~mL} \mathrm{\textrm {min } ^ { - 1 }}$ airflow. They took place between 10 a.m. and 11 a.m., using artificial radiation source (about 1,200 $\mu_{\mathrm{mol} \mathrm{m}}^{-2} \mathrm{~s}^{-1}$ ).

Table 1. Chemical characteristics of the used substrate in the experiment.

\begin{tabular}{|c|c|c|c|c|c|c|c|c|c|c|c|}
\hline M.O. & $\mathbf{N}$ & \multirow{2}{*}{$\mathrm{pH}$} & \multirow{2}{*}{$\begin{array}{c}P \\
\left(\mathrm{mg} \mathrm{kg}^{-1}\right)\end{array}$} & $K$ & $\mathrm{Ca}$ & $\mathrm{Na}$ & $\mathrm{Mg}$ & $\mathrm{H}+\left.\mathrm{A}\right|^{3+}$ & \multirow{2}{*}{ SB } & \multirow{3}{*}{$\begin{array}{l}\begin{array}{l}\text { PST } \\
(\%)\end{array} \\
4\end{array}$} & \multirow{3}{*}{$\begin{array}{c}\begin{array}{c}\mathrm{CE} \\
\left(\mathrm{dS} \mathrm{m}^{-1}\right)\end{array} \\
0.8\end{array}$} \\
\hline & & & & \multicolumn{5}{|c|}{$\left(\mathrm{cmol}_{\mathrm{c}} \mathrm{dm}^{-3}\right)$} & & & \\
\hline 0.93 & 0.05 & 5.4 & 101 & 0.5 & 0.4 & 0.05 & 0.3 & 3.95 & 1.08 & & \\
\hline
\end{tabular}

Table 2. Composition of essential macro and micronutrients from the bovine (BB) and goat (GB) biofertilizer (BIO).

\begin{tabular}{|c|c|c|c|c|c|c|c|c|c|c|}
\hline \multirow{2}{*}{ BIO } & $\mathbf{N}$ & $\mathbf{P}$ & $\mathrm{K}$ & $\mathrm{Ca}$ & $\mathrm{Mg}$ & \multirow{2}{*}{$\begin{array}{c}\mathrm{Ce} \\
\left(\mathrm{dS} \mathrm{m}^{-1}\right)\end{array}$} & $\mathrm{Fe}$ & $\mathrm{Cu}$ & $\mathrm{Zn}$ & $\mathrm{Mn}$ \\
\hline & & & $\left(\mathrm{g} \mathrm{L}^{-1}\right)$ & & & & \multicolumn{4}{|c|}{$\left(\mathrm{mg} \mathrm{L}^{-1}\right)$} \\
\hline BB & 2.73 & 3.1 & 2.3 & 3.1 & 0.6 & 3.8 & 42.6 & 0.2 & 6.1 & 6.1 \\
\hline GB & 0.26 & 0.26 & 4.2 & 4 & 0.9 & 2.9 & 82.6 & 0.1 & 3.8 & 0.8 \\
\hline
\end{tabular}


Observed data were subjected to the analysis of variance by the $\mathrm{F}$ test, those referring to the biofertilizers types were compared by the Tukey test, and those of quantitative nature by regression. For data processing, the computer program "ASSISTAT 7.7 BETA" (Silva \& Azevedo, 2016) was employed.

\section{Results and Discussion}

From the summaries of the analyzes of variance, except for the soil saline status at the experiment end that responded to the isolated effects of water and biofertilizer types, interaction between irrigation water salinity and biofertilizer exerted significant effects on biometric growth and on the dry biomass formation from lima bean plants (Table 3). The soil saline status differs from when Lima Neto et al. (2018) reported significant differences between the soil with and without bovine biofertilizer, due to the salinity increase of irrigation water. On the other hand, it is in agreement with when Medeiros et al. (2016) concluded that the salinity $\times$ bovine biofertilizer interaction significantly interfered with the variables growth, biomass formation and quality of yellow passion fruit (Passiflora edulis Sims) seedlings.

The mean electrical conductivity from soil saturation extract (ECse), increased linearly with the electrical conductivity of the irrigation water (Figure $1 \mathrm{~A}$ ). This result is a reflection of the salts addition by the irrigation waters, i.e., increasing the ECse from 0.08 to 1.3 during the experimental phase. Cavalcante et al. (2011), while irrigating the pine nut cultivation with saline waters, also found an ECse increase in a non-saline Dystrophic Yellow Argisol.

For ECse as a function of the biofertilizers types, Figure 1B points that there was no statistical difference between bovine $\left(\right.$ ECse $\left.=0.90 \mathrm{dS} \mathrm{m}^{-1}\right)$ and goat $\left(E C s e=0.68 \mathrm{dS} \mathrm{m} \mathrm{m}^{-1}\right)$ biofertilizers; however, they differed at the control (SB), which had a mean EC of $0.53 \mathrm{ds} \mathrm{m}^{-1}$. This result differs from Diniz et al. (2013) who presented an EC increase when they applied the biofertilizers as a salt stress attenuator.

Water salinity increase promoted a linear decrease in the number of emitted leaves and the plant stem diameter, with a less intensity in the treatments that had organic input presence (Figure 2).

The number of emitted leaves decreased linearly by $24 \%$ for the SB treatments, $48.5 \%$ and $34.4 \%$ for the BB and $\mathrm{GB}$ treatments, respectively. Even with this reduction, the treatments that had organic input presence were superior to the control. This superiority is supposedly related to the biofertilizers ability in stimulating the proliferation of microorganisms and essential nutrients solubilizers in the soil, increasing their availability to plants (Sousa et al., 2013). Sousa et al. (2017) found a reduction in the number of leaves when performing a study in saline environment with sunflower cultivation. In accordance with this study, Sousa et al. (2016a) also found a reduction in the number of leaves in the corn crop under saline irrigation in a soil with crab biofertilizer.

Irrigation water salinity reduced the stem diameter, but to a lesser extent in treatments with goat and bovine biofertilizers

Table 3. Summary of the analysis of variance for electrical conductivity from soil saturation extract (ECse), leaf number (LN), stem diameter (SD), leaf area (LA), root length (RL), shoot dry weight (SDW) and root dry weight (RDW) of lima bean plants as a function of the substrate salinity levels with and without the application of bovine and goat biofertilizers.

\begin{tabular}{lcccccccc}
\hline \multirow{2}{*}{ Variation sources } & \multirow{2}{*}{ DF } & \multicolumn{9}{c}{ Mean square } \\
\cline { 3 - 8 } & & ECse & LN & SD & LA & RL & SDW & RDW \\
\hline Salinity (S) & 4 & $2.61^{* *}$ & $90.86^{* *}$ & $0.13^{\text {ns }}$ & $159365.60^{* *}$ & $193.85^{*}$ & $2.58^{* *}$ & $0.03^{*}$ \\
Biofertilizers (B) & 2 & $0.88^{*}$ & $194.41^{* *}$ & $0.45^{*}$ & $1406174.97^{* *}$ & $133.84^{*}$ & $12.96^{* *}$ & $0.14^{* *}$ \\
SxB & 8 & $0.30^{\text {ns }}$ & $25.69^{* *}$ & $0.32^{*}$ & $80596.14^{*}$ & $117.63^{*}$ & $1.94^{* *}$ & $0.03^{* *}$ \\
Residue & 60 & 0.18 & 674.66 & 0.14 & 31156.5 & 42.86 & 0.62 & 0.01 \\
Coefficient of variation (\%) & - & 31.9 & 20.4 & 9.7 & 27.87 & 21.15 & 30.28 & 32.59 \\
\hline
\end{tabular}

DF: Degrees of freedom; * Significant by the $\mathrm{F}$ test at $5 \%$; ${ }^{*}$ Significant by the $\mathrm{F}$ test at $1 \%$; $\mathrm{ns}$ : not significant.

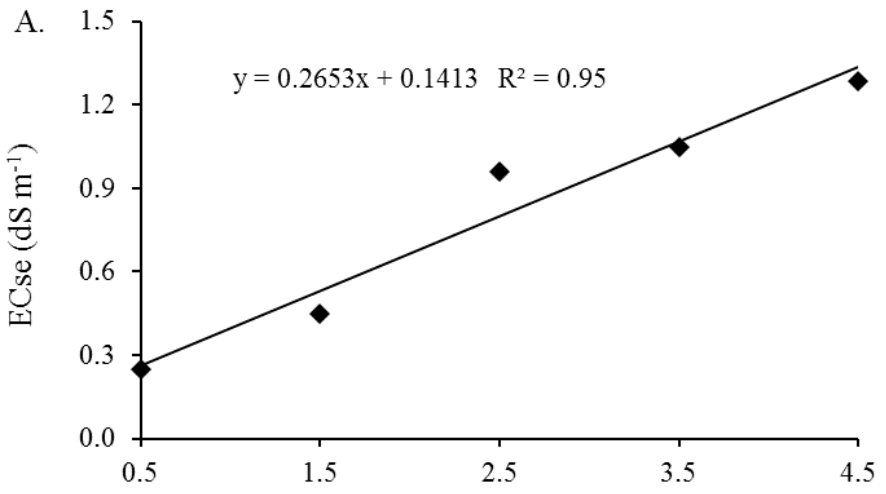

Electrical conductivity of water - $\mathrm{ECw}\left(\mathrm{dS} \mathrm{m} \mathrm{m}^{-1}\right)$

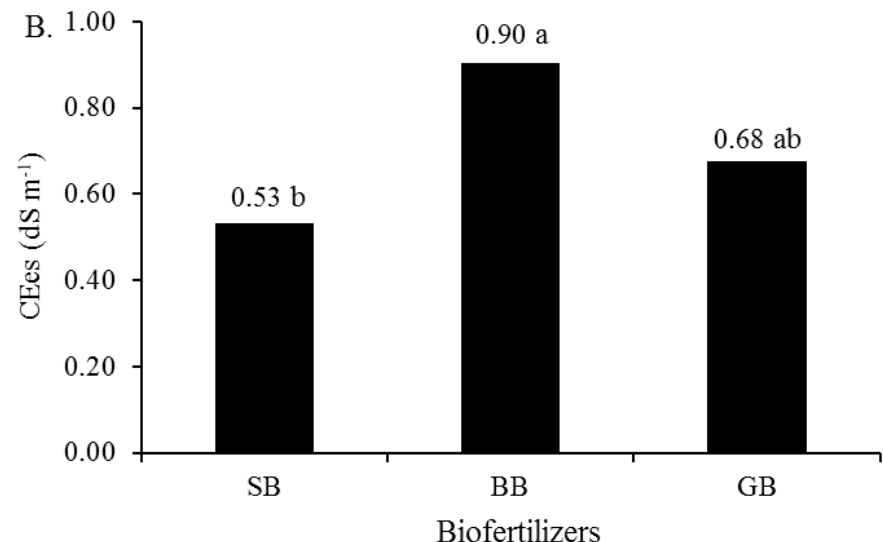

Biofertilizers

Figure 1. Electrical conductivity from soil saturation extract as a function of the substrate water salinity (A) and electrical conductivity from substrate saturation extract (B) without biofertilizer (SB), with bovine biofertilizer (BB), and goat biofertilizer (BC). Means followed by the same letter do not differ from each other by the Tukey test $(p \geq 0.05)$. 

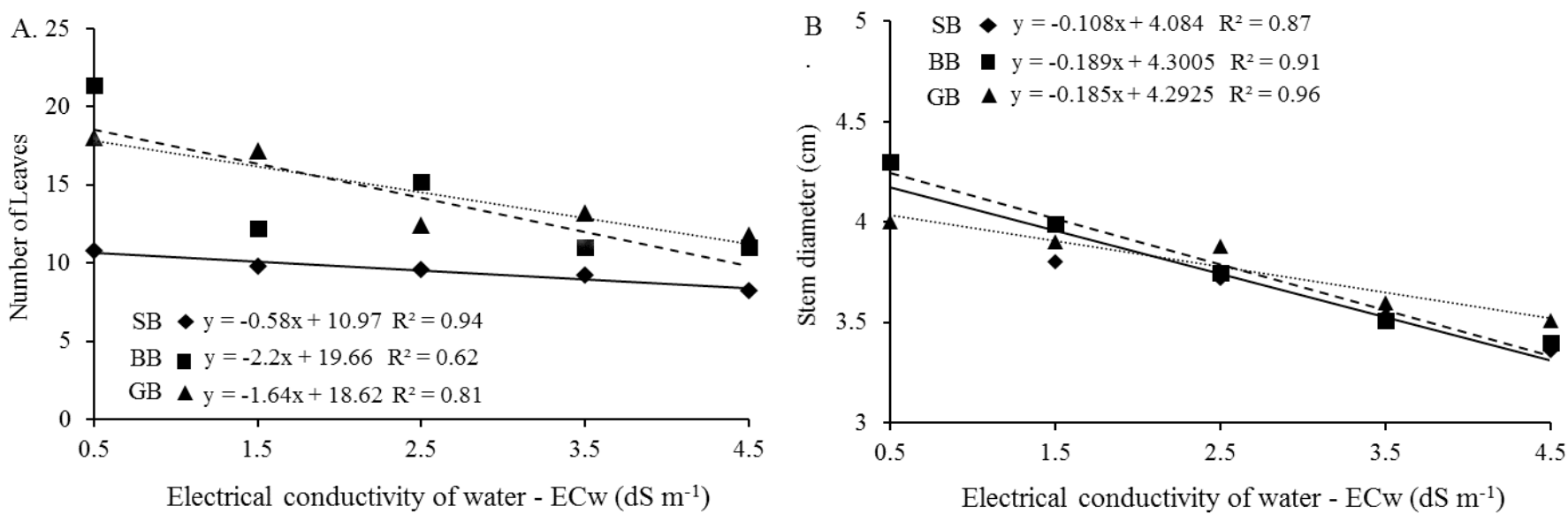

Figure 2. Number of leaves $(A)$ and stem diameter $(B)$ of lima bean plants irrigated with saline waters in substrate without biofertilizer - SB $\bullet(-)$, with bovine biofertilizer - BB $\square(----)$, and goat biofertilizer - GB $\boldsymbol{\Delta}(\ldots .$.$) .$

(Figure 2B). Where the quadratic polynomial model was fitted for treatments with and without biofertilizers.

These results are in accordance with those obtained by Cavalcante et al. (2011), when they found a decrease in stem diameter in in physic nut (Jatropha curcas L.) plants under saline stress. Results also agree with Sousa et al. (2016a), when, evaluating the salt stress in corn plants in a soil with and without biofertilizer prepared with crab remains, found a decline in the stem diameter, in function of water salinity, but with lower intensity in the soil with organic input.

The increase in ECW impaired the leaf area both in the presence and absence of biofertilizers (Figure $3 \mathrm{~A}$ ), presenting a linear model for BB and GB, and a quadratic polynomial model for $S B$, providing in turn a maximum leaf area of $423.3 \mathrm{~cm}^{2}$ for an ECW of $2.43 \mathrm{dS} \mathrm{m}^{-1}$. Assis Júnior et al. (2007) describe that one of the first responses from plants to the water salinity effect is the reduction of leaf growth rate, directly influencing the cell expansion and division processes.

Similar results of leaf area under saline stress were recorded by Cavalcante et al. (2011), in physic nut (Jatropha curcas L.) seedlings. Gomes et al. (2015) observed that the sunflower leaf area, under saline stress, also reduced, but to a lesser extent in treatments that received bovine biofertilizer.
Using bovine biofertilizer as an organic source for cultivation of saline-irrigated radish, Sousa et al. (2016b) also evicted a similar trend when compared to this study.

Increasing salinity of the irrigation water inhibited the main root length, but to a lesser extent in SB and GB treatments, with maximum values of 36.33 and $38.55 \mathrm{~cm}$ for an electrical conductivity of water of 2.62 and $2.44 \mathrm{dS} \mathrm{m}^{-1}$, respectively. While for treatment with bovine biofertilizer, they were affected linearly (Figure 3B).

The results conflict with those of Oliveira et al. (2014) when evaluating the saline stress effect of irrigation water on biostimulated soil on the in physic nut (Jatropha curcas L.) cultivation, found higher root length in plants that received organic fertilizer when compared to the control. For papaya cultivation, Véras et al. (2015) also observed that soils with the bovine biofertilizers presence promoted greater root length of plants when compared to the soil without any type of organic input irrigated with saline waters.

The saline concentration increase of the waters compromised the dry biomass production of the lima bean aerial part (shoot), following the treatments order of: goat manure biofertilizer > bovine biofertilizer > without biofertilizer (Figure 4A). In bovine biofertilizer treatments,

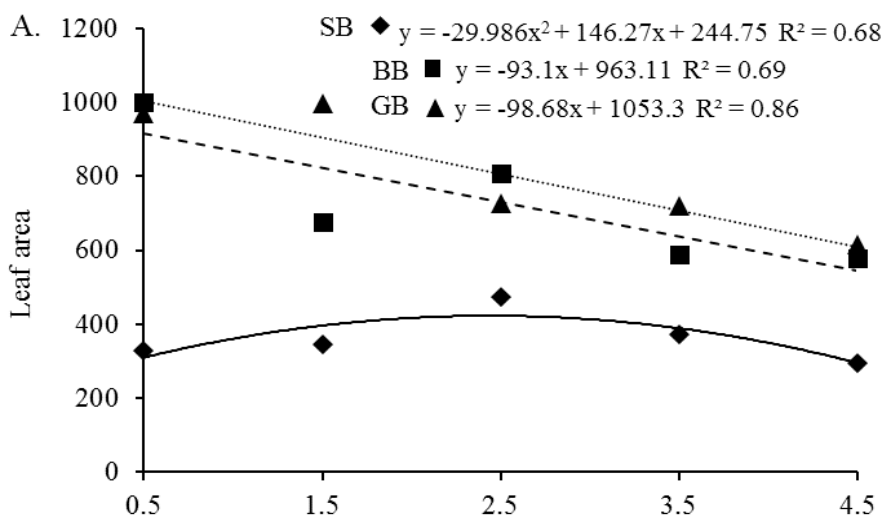

Electrical conductivity of water - $\mathrm{ECw}\left(\mathrm{dS} \mathrm{m}^{-1}\right)$

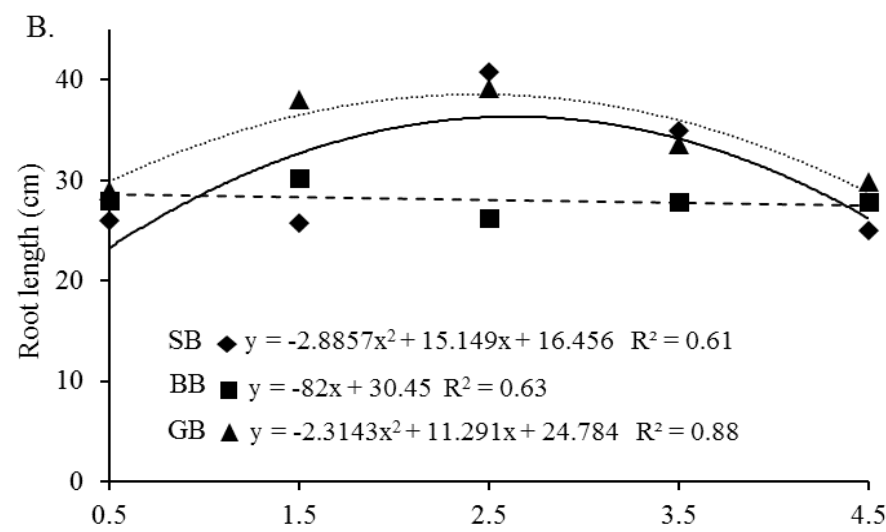

Electrical conductivity of water $-\mathrm{ECw}\left(\mathrm{dS} \mathrm{m}^{-1}\right)$

Figure 3. Leaf area $(A)$ and root length (B) of lima bean plants irrigated with saline waters in substrate without biofertilizer - SB - (-), with bovine biofertilizer - BB $\boldsymbol{\square}(----)$, and goat biofertilizer - GB $\boldsymbol{\Delta}(\ldots .$.$) .$ 

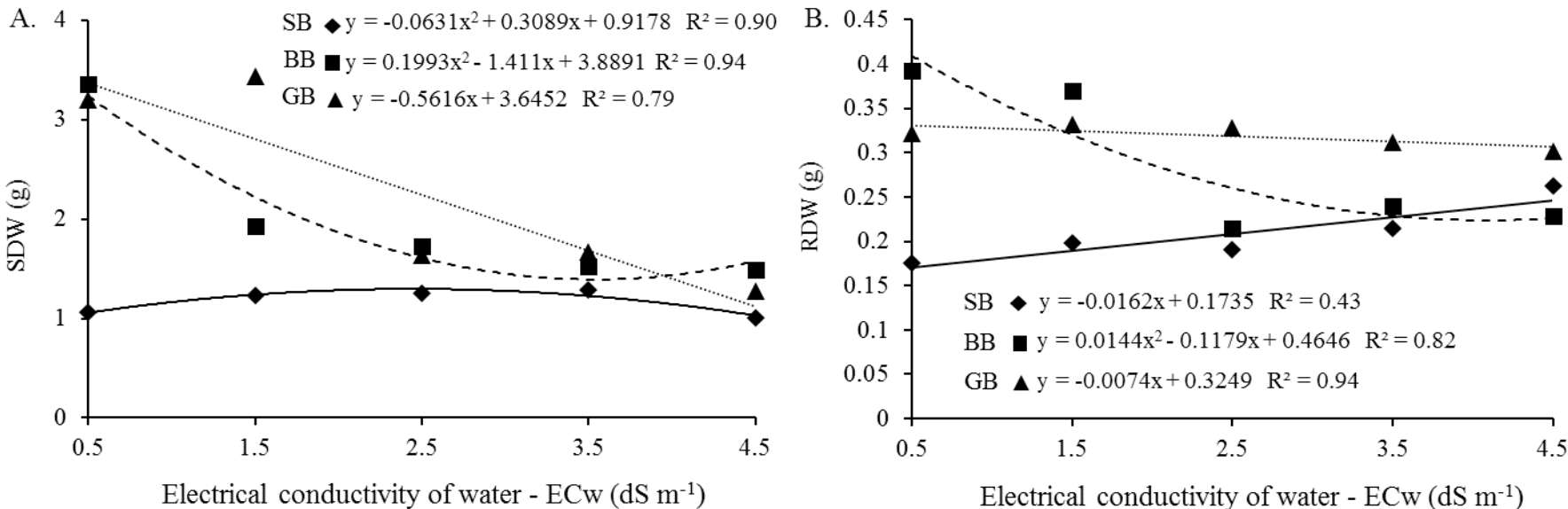

Electrical conductivity of water - ECw $\left(\mathrm{dS} \mathrm{m}^{-1}\right)$

Electrical conductivity of water - $\mathrm{ECw}\left(\mathrm{dS} \mathrm{m} \mathrm{m}^{-1}\right)$

Figure 4. Shoot dry weight $(A)$ and root dry weight $(B)$ of lima bean plants irrigated with saline waters in substrate without biofertilizer - SB SB $\bullet(-)$, with bovine biofertilizer - BB $\mathbf{\square}(----)$, and goat biofertilizer - GB $\boldsymbol{\Delta}($....).

salinity inhibited the dry matter to a minimum value of $1.38 \mathrm{~g}$ for a $3.53 \mathrm{dS} \mathrm{m}^{-1} \mathrm{ECW}$; in a soil without dry matter, the biofertilizer obtained values of $1.29 \mathrm{~g}$ for an ECW of $2.44 \mathrm{dS}$ $\mathrm{m}^{-1}$. In plants treated with goat biofertilizer there was a linear reduction of $60.31 \%$. Reduction of shoot dry weight in plants irrigated with saline water is related to the energy deviation that occurs due to the increase of soil salinity levels; therefore, this reduction may be a reflection from the metabolic energy cost (Meneses et al., 2017).

Sousa et al. (2014), evaluating the effect of saline stress on the cowpea crop, also found a reduction in the SDW at 45 days after the planting. In reference to the increase promoted by the bovine biofertilizer, Sousa et al. (2016a) also found similar results in corn crop fertilized with crab biofertilizer under saline stress.

Root dry weight was affected by the increasing salinity of irrigation waters, but its effect was attenuated by the application of biofertilizers. It was observed, according to Figure $4 \mathrm{~B}$, that the quadratic polynomial model was the best fit for all treatments, $\mathrm{SB}, \mathrm{BB}$ and $\mathrm{GB}$, with values of $0.22 \mathrm{~g}$ for an $\mathrm{ECW}$ of $2.73 \mathrm{dS} \mathrm{m}^{-1}, 0.22 \mathrm{~g}$ for an ECW of $4.09 \mathrm{dS} \mathrm{m} \mathrm{m}^{-1}$ and $0.41 \mathrm{~g}$ for an ECW of $1.9 \mathrm{dS} \mathrm{m} \mathrm{m}^{-1}$, respectively. Similar results were obtained by Oliveira et al. (2014), in which the biostimulant presented higher values than the control treatment in the dry weight of the physic nut irrigated with saline water and by Diniz et al (2013), when working on neem (Azadiractha indica A. Juss.) plants with bovine biofertilizer and under saline stress.

In the summary of the analysis of variance (Table 4) it was observed that the photosynthetic rate $(A)$, transpiration rate (E) and stomatal conductance (gs) variables all had an effect on the salinity factors of irrigation water and biofertilizers (bovine and goat).

Although the photosynthesis (A) was initially stimulated, transpiration (E) and stomatal conductance (gs) decreased with the increasing saline concentration of irrigation waters (Figure 5).

The increase in water salinity raised the photosynthetic capacity of plants to the highest value of $13.58 \mu \mathrm{mol} \mathrm{m} \mathrm{m}^{-2} \mathrm{~s}^{-1}$ in plants irrigated with water of the maximum estimated salinity
Table 4. Summary of analysis of variance for photosynthesis (A), transpiration (E) and stomatal conductance (gs) as a function of irrigation water salinity levels in substrate with and without bovine and goat biofertilizer.

\begin{tabular}{lcccc}
\hline \multirow{2}{*}{ Variation sources } & \multirow{2}{*}{ DF } & \multicolumn{3}{c}{ Mean square } \\
\cline { 3 - 5 } & & A & E & gs \\
\hline Salinity (S) & 4 & $34.74^{*}$ & $11.08^{* *}$ & $0.03^{* *}$ \\
Biofertilizer (B) & 2 & $828.59^{* *}$ & $80.35^{* *}$ & $0.18^{* *}$ \\
SxB & 8 & $16.02^{\text {ns }}$ & $1.45^{\text {ns }}$ & $0.005^{\text {ns }}$ \\
Residue & 60 & 10.32 & 1.56 & 0.003 \\
Coefficient of variation (\%) & - & 25.78 & 29.14 & 32.35 \\
\hline
\end{tabular}

DF: Degrees of freedom; * Significant by the $\mathrm{F}$ test at $5 \%$; ${ }^{*}$ Significant by the $\mathrm{F}$ test at $1 \%$; ns: not significant.

of $1.25 \mathrm{dS} \mathrm{m}^{-1}$, and when above this value photosynthesis was gradually inhibited in the lima bean (Figure 5A).

It is noteworthy to say that the reductions in photosynthetic rates due to saline stress can be attributed to a decrease in cell expansion that precedes the inhibition of the photosynthetic process (Neves et al., 2009), causing a partial stomatal closure, and consequently also a reduction in the availability of $\mathrm{CO}_{2}$ to leaves (Gomes et al., 2015). These results are in agreement with Sousa et al. (2014), when studying the effects of irrigation water salinity on the cowpea crop.

Figure 5B shows that there was a significant reduction in the transpiration with increasing salt concentration in the irrigation water. This reduction may have been caused by the partial closure of stomata in response to the irrigation water salinity, as the continuous application of saline stress reduces transpiration, regardless of the plants phenological state (Neves et al., 2009).

Results found in this study are in conformity with Gomes et al. (2015), who also observed a decreasing trend when evaluating the transpiration in sunflower plants irrigated with saline waters and by Sousa et al. (2014) in the cowpea crop.

Increasing saline levels of irrigation water linearly stimulated stomatal conductance (Figure 5C). The stress caused by excess ions generally decreases $\mathrm{CO}_{2}$ assimilation, stomatal conductance, and plant transpiration (Gomes et al., 2015). 


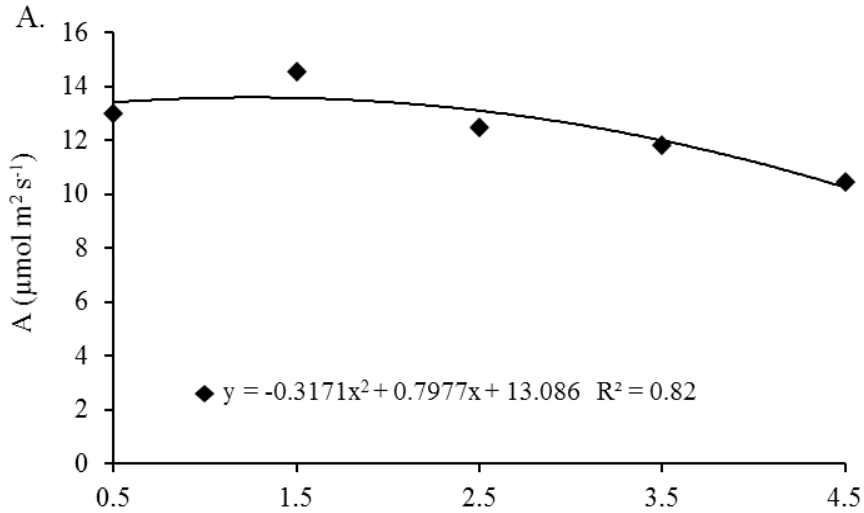

Electrical conductivity of water - $\mathrm{ECw}\left(\mathrm{dS} \mathrm{m}^{-1}\right)$

B.

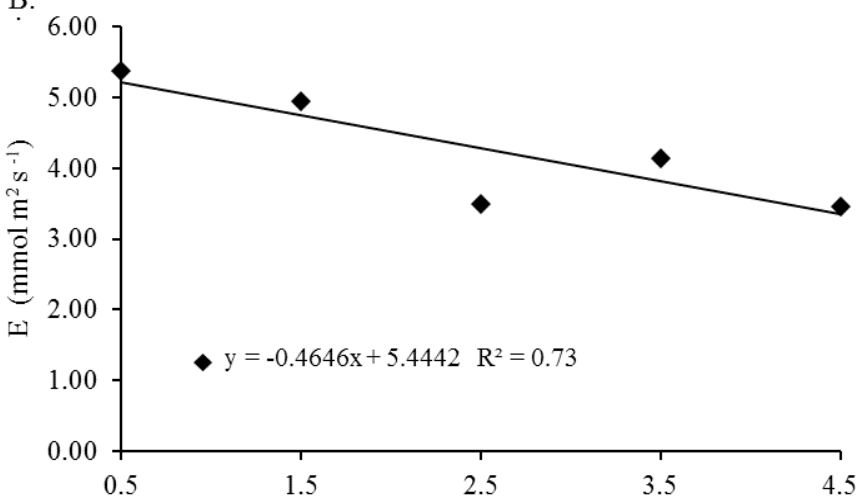

Electrical conductivity of water - ECw $\left(\mathrm{dS} \mathrm{m}^{-1}\right)$

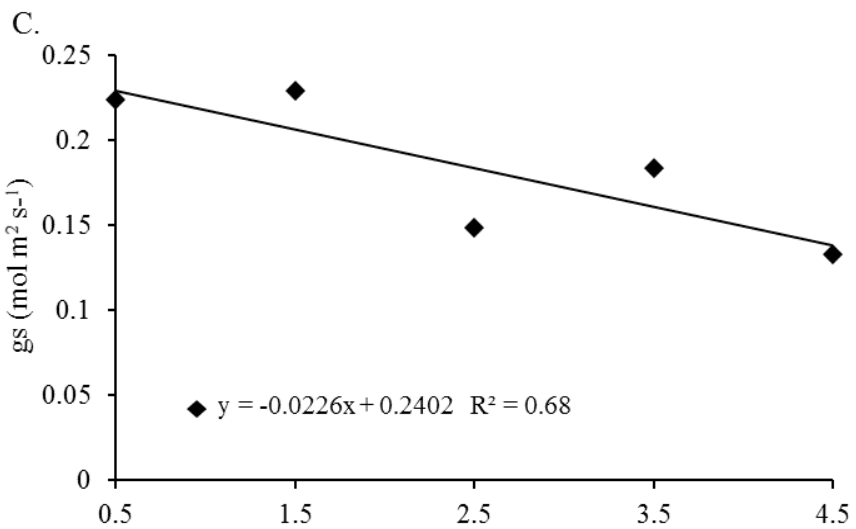

Electrical conductivity of water - ECw $\left(\mathrm{dS} \mathrm{m}^{-1}\right)$

Figure 5. Photosynthesis (A), transpiration (B) and stomatal conductance $(C)$ values in lima bean plants as a function of electrical conductivity from the irrigation water.

This study is in agreement with what was found by Neves et al. (2009), where increased saline levels of irrigation waters impaired stomatal conductance in saline-treated crowpea plants. Sousa et al. (2014) also describe that saline stress decreased the stomatal conductance of cowpea plants.

Biofertilizers addition to the soil resulted in an increase in gas exchange variables, surpassing the treatments without the respective inputs in this order: bovine manure > goat manure $>$ soil without biofertilizer (Figure 6).

Regarding Figure 6A, it was found that treatment with bovine biofertilizer was superior to the control one (7.44
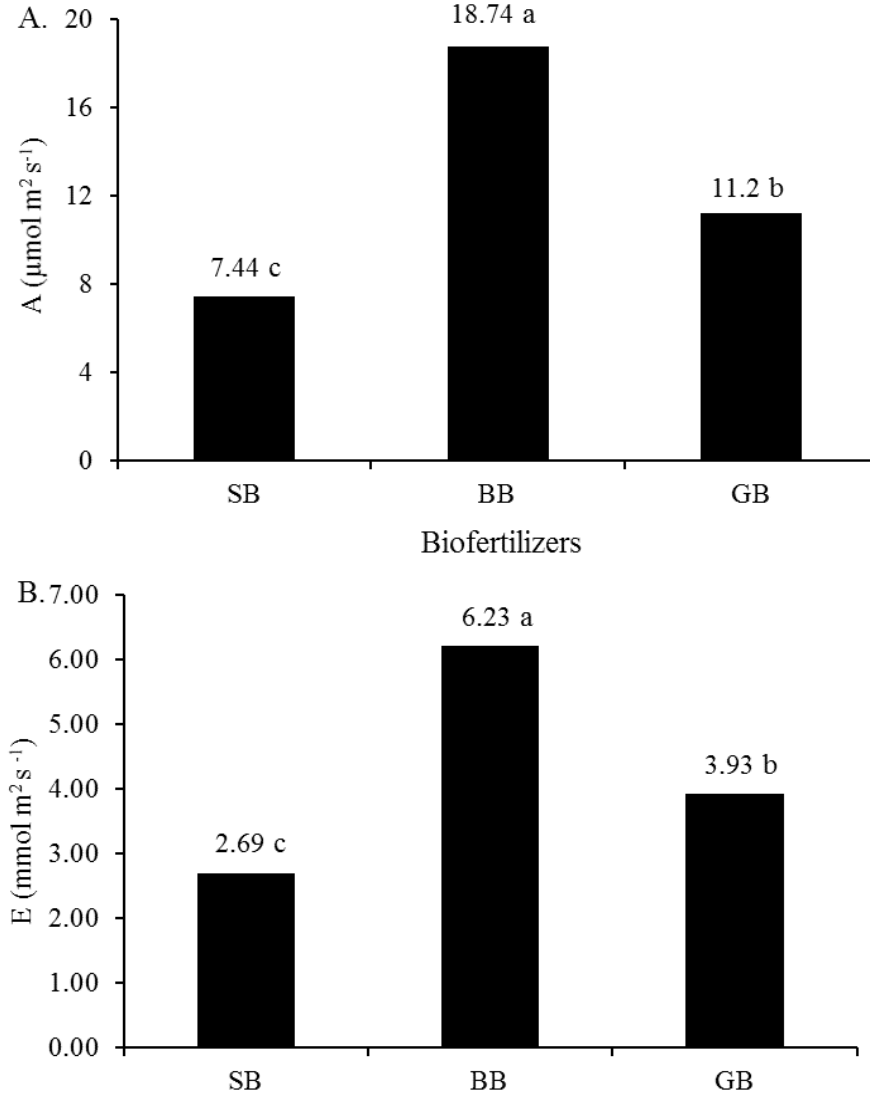

Biofertilizers

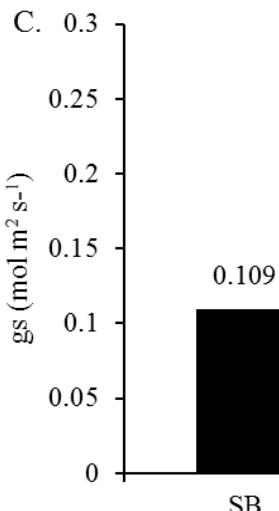

0.277 a

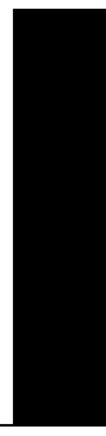

BB

$0.163 \mathrm{~b}$

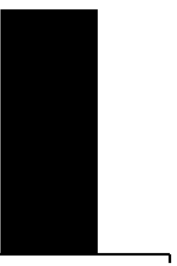

GB

Biofertilizers

Figure 6. Photosynthesis (A), transpiration (B) and stomatal conductance $(C)$ values in lima bean plants as a function of treatments without biofertilizers (SB), bovine (BB) and goat (GB) biofertilizers. Means followed by the same letter do not differ from each other by the Tukey test. $(p \geq 0,05)$.

$\left.\mu \mathrm{mol} \mathrm{m}^{2} \mathrm{~s}^{-1}\right)$ and the goat biofertilizer one $\left(11.2 \mu \mathrm{mol} \mathrm{m}^{2}\right.$ $\mathrm{s}^{-1}$ ). The superiority of this organic input may be related to its nitrogen content, thus providing a higher chlorophyll content and, consequently, photosynthesis. These results corroborate those of Sousa et al. (2013) when stating that increasing concentrations of bovine biofertilizer raised the photosynthetic rate of the physic nut.

In Figure 6B, higher mean transpiration values are revealed in treatments with bovine biofertilizer $\left(6.23 \mathrm{mmol} \mathrm{m}^{2} \mathrm{~s}^{-1}\right)$ when compared to the control $\left(2.69 \mathrm{mmol} \mathrm{m}^{2} \mathrm{~s}^{-1}\right)$ and goat 
biofertilizer $\left(3.93 \mathrm{mmol} \mathrm{m}^{2} \mathrm{~s}^{-1}\right)$. This result may be related to the dead mulching effect proposed by the biofertilizer, i.e., decreasing the soil evaporation and providing greater osmotic adjustment of plants (Sousa et al., 2013). Evaluating the effect of bovine biofertilizer as organic fertilizer on melon culture, Viana et al. (2013) also observed a positive effect on the transpiration of the leaves from this crop.

For stomatal conductance (Figure $6 \mathrm{C}$ ), treatments with

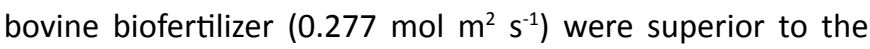
control $\left(0.109 \mathrm{~mol} \mathrm{~m}^{2} \mathrm{~s}^{-1}\right)$ and to goat biofertilizer $(0.163 \mathrm{~mol}$ $\mathrm{m}^{2} \mathrm{~s}^{-1}$ ). This is due to an improvement in the nutritional supply to the plant, in other words, the inadequate supply of essential elements to the plants causes physiological disturbances to them (Taiz et al., 2017). Similarly, Viana et al. (2013) found higher stomatal conductance in melon leaves when fertilizing it with bovine biofertilizer.

\section{Conclusions}

Goat manure biofertilizer promoted higher biometric growth and lima bean biomass production than the bovine manure biofertilizer.

Bovine manure biofertilizer was more efficient in photosynthesis, transpiration and stomatal conductance than the goat manure.

Both biofertilizers attenuate soil salinity induced by irrigation waters salinity in relation to a soil without any organic input; however, there was continuity of the growth effects on plant physiology.

\section{Literature Cited}

Assis Junior, J.O.; Lacerda C.F.; Silva F.B.; Silva, F.L.B.; Bezerra, M.A.; Gheyi, H.R. Produtividade do feijão-de-corda e acúmulo de sais no solo em função da fração de lixiviação e da salinidade da água de irrigação. Revista Engenharia Agrícola, v. 27, n. 3, p.702-713, 2007.https://doi.org/10.1590/S0100-69162007000400013.

Cavalcante, L.F.; Rebequi, A.M.; Sena, G.S.A. de; Nunes, J.C. Irrigação com águas salinas e uso de biofertilizante bovino na formação de mudas de pinhão-manso. Irriga, v.16, n.3, p.288-300, 2011. https://doi.org/10.15809/irriga.2011v16n3p288.

Diniz, B.L.M.T.; Cavalcante, L.F.; Mesquita, F.O.; Lima Neto, A.J.; Nunes, J.C.; Diniz Neto, M.A. Crescimento inicial e consumo hídrico de nim submetido ao estresse salino e biofertilizante bovino. Revista Brasileira de Ciências Agrárias, v.8, n.3, p.470475, 2013. https://doi.org/10.5039/agraria.v8i3a2613.

Empresa Brasileira de Pesquisa Agropecuária - Embrapa. Centro Nacional de Pesquisa de Solos. Manual de métodos de análises de solo. 2.ed. Rio de Janeiro: Embrapa; CNPS, 1997. 212 p.

Gomes, K.R.; Sousa, G.G.de; Lima, F.A.; Viana, T.V.A.; Azevedo, B.M.; Silva, G.L. Irrigação com água salina na cultura do girassol (Helianthus annuus L.) em solo com biofertilizante bovino. Irriga, v.20, n.4, p.680-693, 2015. https://doi.org/10.15809/ irriga.2015v20n4p680.

Köppen, W.P. Die klimate der erde: Grundriss der klimakunde. Berlin: Walter de Gruyter \& So., 1923. 369p.
Lima Neto, A.J. de; Cavalcante, L.F.; Nunes, J.C.; Souto, A.G. de L.; Bezerra, F.T.C. Mudas de tamarindeiro irrigadas com água salina em solo sem e com biofertilizantes. Irriga, v.20, n.4, p.730-744, 2015. https://doi.org/10.15809/irriga.2015v20n4p730.

Lima, A.D.; Sousa, C.H.C.; Lacerda, C.F de; Bezerra, M.A.; Silva, E.N.; Neves, A.L.R. Gas exchange of four woody species under salinity and soil waterlogging. Revista Brasileira de Engenharia Agrícola e Ambiental, v.21, n.10, p.670-674, 2017. https://doi. org/10.1590/1807-1929/agriambi.v21n10p670-674.

Medeiros, S.A.S.; Cavalcante, L.F.; Bezerra, M.A.F.; nascimento, J.A.M.; Bezerra, F.T.C.; prazeres, S.S. Água salina e biofertilizante de esterco bovino na formação e qualidade de mudas de maracujazeiro amarelo. Revista Irriga, v. 21, n. 4, p. 779-795, 2016. https://doi.org/10.15809/irriga.2016v21n4p779-795.

Menezes, R.V.; Azevedo Neto, A.D. de; Ribeiro, M.O.; Cova, A.M.W. Growth and contents of organic and inorganic solutes in amaranth under salt stress. Pesquisa Agropecuária Tropical, v. 47, n. 1, p. 22-30, 2017. https://doi.org/10.1590/1983-0632016v4742580.

Neves, A.L.R.; Lacerda, C.F.; Guimarães, F.V.A.; Gomes Filho, E.; Feitosa, D.R.C. Trocas gasosas e teores de minerais no feijão-decorda irrigado com água salina em diferentes estádios. Revista Brasileira de Engenharia Agrícola e Ambiental, v. 13, supl., p. 873 881, 2009. https://doi.org/10.1590/S1415-43662009000700009.

Oliveira, F. de A. de.; Alves, R. de C.; Bezerra, F. M. S.; Lima, L. A.; Cavalcante, A. L. G.; Medeiros, J. F. de. Interação entre salinidade e biostimulante no desenvolvimento inicial do pinhão manso. Revista Irriga, v. 19, n. 4, p. 694-704, 2014. https://doi. org/10.15809/irriga.2014v19n4p694.

Oliveira, F. N.; Torres, S. B.; Benedito, C. P. Caracterização botânica e agronômica de acessos de feijão fava, em Mossoró, RN. Revista Caatinga, v. 24, n. 1, p. 143-148, 2011. https://periodicos.ufersa. edu.br/index.php/caatinga/article/view/1936/4665. 06 Jan. 2018.

Puértolas, J.; Larsen, E.K.; Davies, W.J.; Dodd, I.C. Applying 'drought' to potted plants by maintaining suboptimal soil moisture improves plant water relations. Journal of Experimental Botany, v.68, n.9, p.2413-2424, 2017. https://doi.org/10.1093/jxb/erx116.

Rhoades, J.D.; Kandiah, A.; Mashali, A.M. Uso de águas salinas para produção agrícola. Campina Grande: UFPB, 2000. 117p.

Sá, F.V. da S.; Paiva, E. P. de.; E.F. de.; Bertino, A.M.P.; Barbosa, M.A.; Souto, L.S. Tolerance of castor bean cultivars under salt stress. Revista Brasileira de Engenharia Agrícola e Ambiental, v.20, n.6, p.557-563, 2016. https://doi.org/10.1590/1807-1929/agriambi. v20n6p557-563.

Silva, F. A. S.; Azevedo, C. A. V. The Assistat Software Version 7.7 and its use in the analysis of experimental data. African Journal Agricultural Research, v. 11, n. 39, p. 3733 - 3740, 2016. https:// doi.org/10.5897/AJAR2016.11522.

Sousa, G.G. de; Viana, T. V. de A.; Rebouças Neto, M. de O.; Silva, G. L.; Azevedo, B. M.; Costa, F. R. B. Características agronômicas do girassol irrigado com águas salinas em substratos com fertilizantes orgânicos. Revista Agrogeoambiental, v. 9, n. 1, p. 65-75 2017. https://doi.org/10.18406/2316-1817v9n12017920.

Sousa, G.G.; Rodrigues, V.S.; Viana, T.V.A.; Silva, G.L.; Rebouças Neto, M.O.; Azevedo, B.M. Irrigação com água salobra na cultura do rabanete em solo com fertilizantes orgânicos. Revista Brasileira de Agricultura Irrigada, v.10, n.6, p. 1065-1074, 2016a. https:// doi.org/10.7127/RBAI.V10N600514. 
Sousa, G.G.; Viana, T.V. de A.; Lacerda, C.F.; Azevedo, B.M.; Silva, G.L.; Costa, F.R.B. Estresse salino em plantas de feijão-caupi em solo com fertilizantes orgânicos. Revista Agro@mbiente, v.8, n.3, p. 359-367, 2014. https://doi.org/10.18227/1982-8470ragro. v8i3.1824.

Sousa, G.G.; Viana, T.V.A.; Braga, E.S.; Azevedo, B.M.; Marinho, A.B.; Borges, F.R. M. Fertirrigação com biofertilizante bovino: efeitos no crescimento, trocas gasosas e na produtividade do pinhãomanso. Revista Brasileira de Ciências Agrárias, v.8, n.3, p.503509, 2013. https://doi.org/10.5039/agraria.v8i3a2288.

Sousa, G.G.; Viana, T.V.A.; Silva, G.L.; Dias, C.N.; Azevedo, B.M. Interação entre salinidade e biofertilizante de caranguejo na cultura do milho. Magistra, v. 28, n.1, p. 44-53, 2016b. https:// magistraonline.ufrb.edu.br/index.php/magistra/article/ view/194/231. 04 Jan. 2018.

Taiz, L.;Zeiger, E.; Moller, I. M.; Murphy, A. Fisiologia e desenvolvimento vegetal. 5.ed. Porto Alegre: Artmed, 2017. 819p.
Vasconcelos, R.R.A. de; Barros, F.C. M.; Silva, E. de F.; Graciano, E.S.A.; Fontenele, A.J. P.B.; Silva, N.M.L. da. Características físicas de solos salino-sódicos do semiárido pernambucano em função de diferentes níveis de gesso. Revista Brasileira de Engenharia Agrícola e Ambiental, v.17, n.12, p.1318-1325, 2013. https://doi. org/10.1590/S1415-43662013001200010.

Véras, M. L. M.; Melo Filho, J. S. de M.; Araújo, D. L. de; Alves, de. S. A.; Irineu, T. H. da. S.; Andrade, R. Salinidade da água e biofertilizante bovino na formação de mudas de mamoeiro (Carica papaya L.). Revista Agropecuária Técnica, v.36, n.1, p. 212-221, 2015. http:// periodicos.ufpb.br/ojs/index.php/at/issue/view/1559. 05 Nov. 2017.

Viana, T.V. de A.; Santos, A.P.G.; Sousa, G.G. de; Pinheiro Neto, L.G.; Azevedo, B.M.; Aquino, B.F. Trocas gasosas e teores foliares de NPK em meloeiro adubado com biofertilizantes. Revista Brasileira de Ciências Agrárias, v.8, n.4, p.595-601, 2013. https://doi. org/10.5039/agraria.v8i4a3260. 